\title{
INVESTIGATION AND OPTIMIZATION OF EDM PERFORMANCE MEASURES USING
}

\author{
EMPIRICAL DATA ANALYSIS
}

\author{
Kalyani S. Kanekar ${ }^{1}$, Diwesh B. Meshram ${ }^{2}$ \\ ${ }^{I}$ Dept. of Mechanical Engg Dr. Babasaheb Ambedkar collage of Engg. And research Wanadongari (Nagpur), \\ Maharashtra, India. \\ kalyanikk18@gmail.com \\ ${ }^{2}$ Dept. of Mechanical Engg Dr. Babasaheb Ambedkar collage of Engg. And research Wanadongari (Nagpur), \\ Maharashtra, India. \\ diweshs@gmail.com
}

\begin{abstract}
In this paper research is aimed to investigate and optimization of EDM performance measures in order to find out best ideal EDM electrode having higher material removal rate, improved surface finish and lower electrode wear rate. For this four EDM electrodes of four different materials (viz. Gr, $\mathrm{Cu}, \mathrm{Br}$ and $\mathrm{Al}$ ) are developed by three different manufacturing methodologies. Electrode design is very time consuming process and done interactively using CAD system. In this research work Vertical Milling Machine, Net Shape Casting and Die Sinking EDM do EDM electrodes fabrication. After the electrode Fabrication testing of electrodes is done on Die Sinking EDM. For optimization two different advanced methods of optimization SAW \& TOPSIS are used for analysis of EDM performance measures and to predict optimal choice of each EDM electrode. The analysis of both optimization methods reveals Copper is best EDM electrode followed by Brass, Aluminium and Graphite. Experimental results are provided to verify this approach.
\end{abstract}

Key Words: EDM, MRR, EWR, SR, OPTIMIZATION, SAW, TOPSIS

\section{INTRODUCTION}

EDM is one of the main non-conventional machining process in which current is converted into heat. EDM is a thermal process in which rapid and continuous spark is discharged between electrically conductive workpiece and electrode in dielectric medium such as kerosene [1]. Now a day the advance materials viz. super alloys, ceramic \& composites have wide applications in industrial equipment's and aerospace industry due to their excellent properties like high strength, high bending stiffness, low thermal expansion, better fatigue characteristics. These advance materials are used in aero engine components, automotive ceramic gas turbine, nuclear reactors etc. Thus present manufacturing industries facing challenges from these super alloys as they are very hard and difficult to machining, required high precision and surface quality which increase machining cost. The solution to meet these requirements and to survive in these challenges is use of EDM. EDM plays excellent role in machining difficult to machine material and complicated geometries with better surface finish and dimensional accuracy which is impossible to achieve by other conventional machining [2]. But EDM electrode manufacturing is very time consuming and expensive process. It have been observed that major cost and time for manufacturing of electrode could occupy more than $50 \%$ of total machining cost [3]. Thus correct selection of manufacturing condition is one of the most important aspects to take into consideration during electrode manufacturing. The aim is to produce and evaluate EDM electrodes manufactured by various manufacturing technologies. In this research electrodes are fabricated by vertical milling machining (WMC), Net shape casting and Die sinking EDM process. Vertical Milling Machine (WMC) is a computer-controlled process and thus two main electrodes $(\mathrm{Cu} \& \mathrm{Gr})$ are manufactured by Vertical milling machine operation. In WMC, system can be manually programmed and accept files from CAD system. There for first electrode is design in Unigraphics 9 software and this $\mathrm{CAD}$ file is then used for making program for WMC operation. Brass electrode is fabricated using Net Shape Casting process. Net Shape Casting is a process in which cast part is produced by forming mould from sand mixture and then pouring molten metal into it. Copper electrode is used for mould making in this process. Aluminium electrode is directly manufactured by Die Sinking EDM process using Graphite as a master tool manufactured by WMC process. All electrodes are tested on Die sinking EDM machine using same workpiece of $5 \mathrm{~mm}$ thick MS sheet. To find out best manufacturing technology comparison is takes place between all three manufacturing methodologies on the basis of Cost \& time. Performance of EDM process is measured with respect to the Material Removal Rate (MRR), Electrode Wear Rate (EWR) and Surface Finish of workpiece. Optimization is done under four criteria: MRR, EWR, SR \& Total Cost of electrode. The methods used for Optimization are Simple Addictive Weighting (SAW) and Technique for Order Preference by Similarities to an Ideal Solution (TOPSIS) to find out best optimal solution of electrode among all four electrodes. 


\section{METHEDOLOGY}

Fabrication of EDM electrode is very difficult and timeconsuming task. Considering the overall literature review through research paper and market survey, it was observed that most of problems are related to complex shape. Methodology adopted for this research work is shown in below figure.

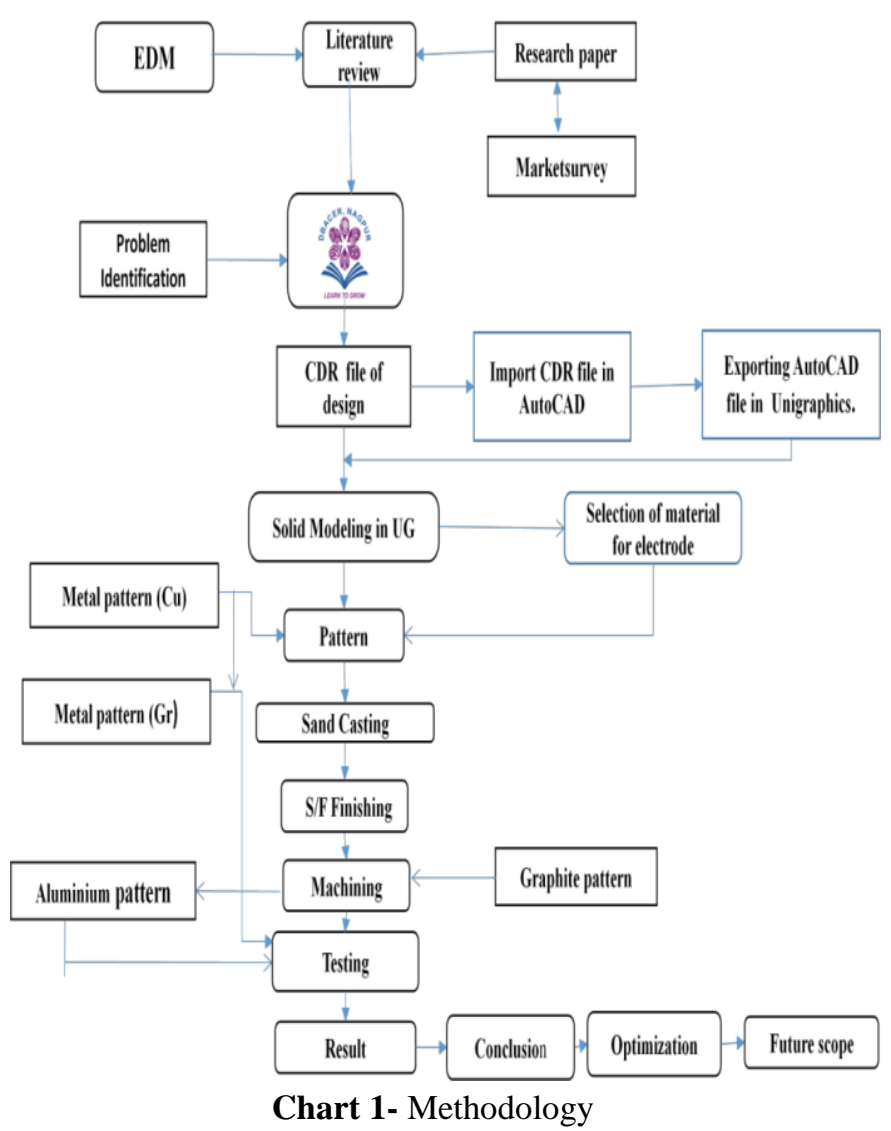

\subsection{Modeling Of Electrode Design}

Modeling of electrode is done in latest Unigraphics 9 software. But we have only jpg file of design, which is not clear enough for solid modeling of the part. Thus first step is to Re-design college logo into coral draw software. With the Re-design model gives the clear \& good appearance and aesthetic to the design. Once the part is Re-Design into coral draw software the coral draw file is directly imported to the CAD-Model by using Auto-Cad software. This CADModel is again imported into NX-Model by using latest Unigraphics-9 software and complete solid modeling of part is done in this software.

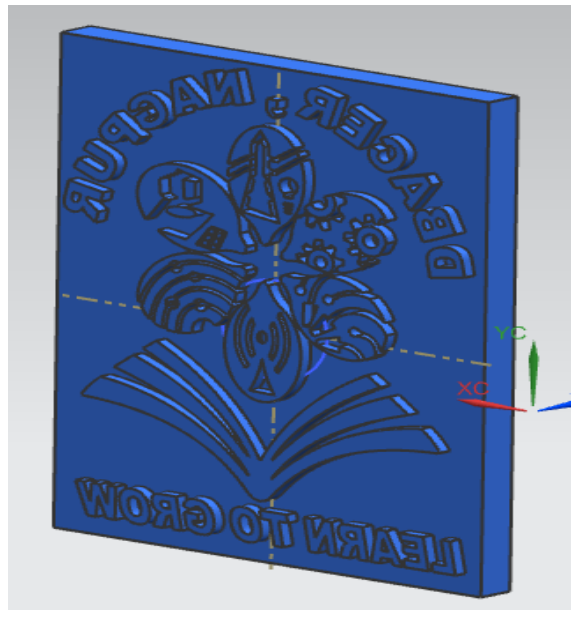

Figure 1 Solid Model of Electrode design in Unigraphics software

\subsection{Material Selection}

Selection of material for EDM tool is one of the important step in research. Owing to the increased development in field of EDM, it is very important to select material having higher material removal rate, lower electrode wear rate and improved surface finish. For material selection number of research papers are reviewed which shows Graphite, Copper, Brass\& Aluminium are best material for EDM electrode [4], [5], [11]. On this basis following four material are selected,
1. Graphite
2. Copper
3. Brass
4. Aluminium

\section{EXPERIMENTAL PROCESS}

This is the main step in research. The aim is to produce EDM electrodes by different manufacturing methods and compare the performance parameter of each electrode. After fabrication of the EDM Electrode, finishing and testing is done on Die-sinking EDM machine using constant workpiece $(5 \mathrm{~mm}$ thick MS sheet). During testing of electrode a hole is drilled on the topside of electrode for fixing the electrode in holder.

\subsection{Manufacturing Methodology No.1}

\section{(Fabrication Of Copper \& Graphite Electrode By}

\section{Vertical Milling Machine)}

This methodology helps in fabricating metal electrode by using Vertical milling machine at optimized cost with good dimensional accuracy. The flow process chart in figure I gives the information about fabrication of the metal pattern. For Vertical Milling Operation first requirement is to create NC- part program of the solid model of electrode design. Selection of tool (mill bore) is also important part for this machining operation. Once the part program is completed actual machining of the electrode is start. For first one hour 
$4 \mathrm{~mm}$ milling cutter is used to remove excessive material from work part, then for next two hour $1.5 \mathrm{~mm}$ diameter milling cutter is used and finally for critical portion of electrode design $1 \mathrm{~mm}$ diameter milling cutter is used for next three hours. So time required for machining of copper and graphite electrode is 6 hours for each electrode. This operation is done at Spindle speed $=3000 \mathrm{rpm}$, Feed rate $=1000 \mathrm{~mm} / \mathrm{min}$ and Depth of cut $=0.2 \mathrm{~mm}$. after electrode fabrication testing is done at constant machining set up on Die Sinking EDM. This testing is done on MS sheet of $5 \mathrm{~mm}$ thickness at $\mathrm{I}=15 \mathrm{~A}$.

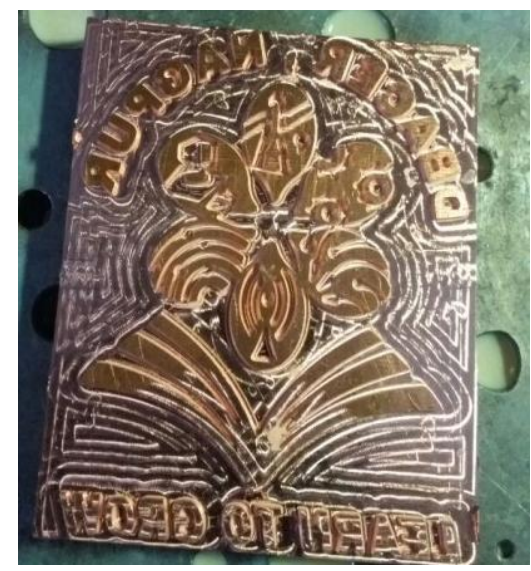

Figure 2. Finished $\mathrm{Cu}$ electrode

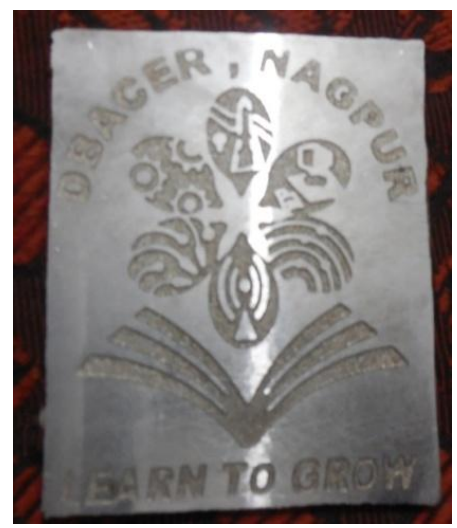

Figure 3. Tested MSBy Cu electrode



Figure 4 Finished Gr electrode

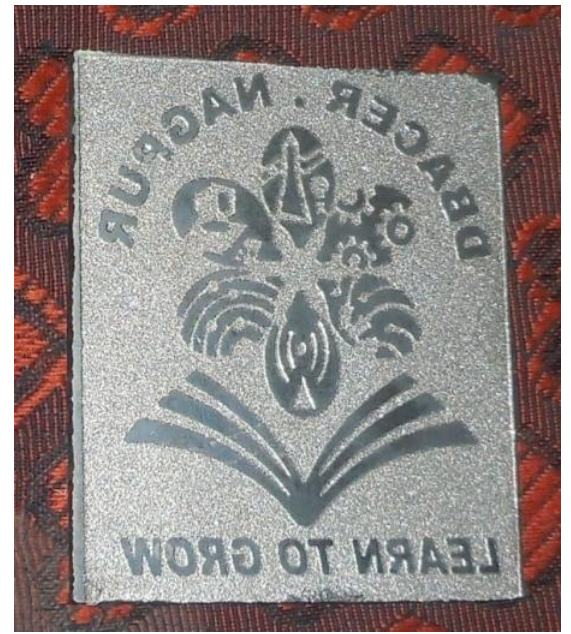

Figure 5 Tested MS Workpiece By Gr Electrode

\subsection{Manufacturing Methodology No.2}

\section{(Net Shape Casting of Brass electrode)}

Net shape casting is a process by which cast part produced by forming a mould from a sand mixture and then pouring molten liquid metal into the cavity in the mould. The material used in this process was brass. For the net shape casting first important requirement is pattern making. We use copper electrode created by the WMC machining process as a pattern for the net shape casting. Mould is developed using copper tool as a pattern from a sand mixture and then pouring molten liquid of brass material into the cavity in the mould. The mould is then cooled until the metal has solidified. At last, the casting is separated from the mould. The next step was the finishing of the cast electrode. This operation was performed on the Lathe. The finishing process help in getting the surface flatness and having removing burr from the electrode. The finish Electrode has to be tested on the Die- Sinking EDM machine. The workpiece and all the other parameters was constant and same in the VMC machining operation

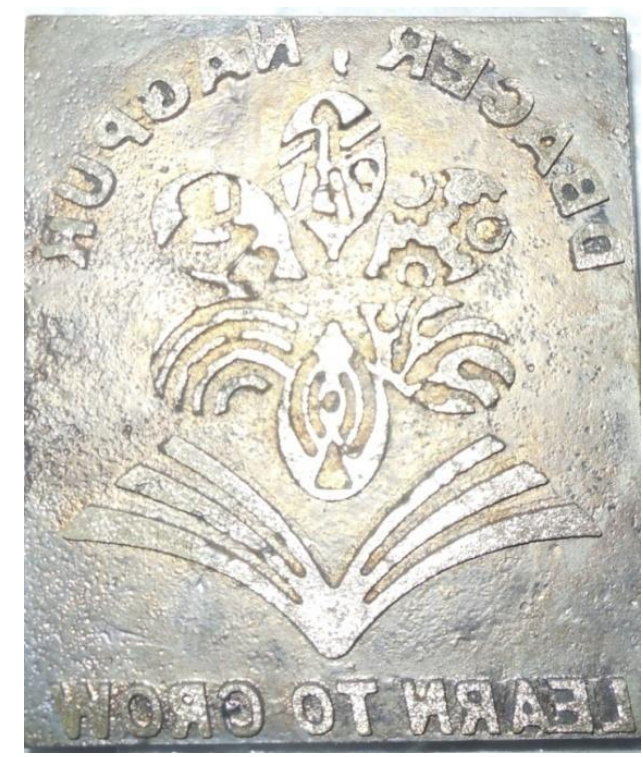

Figure 6 Finished Br Electrode 


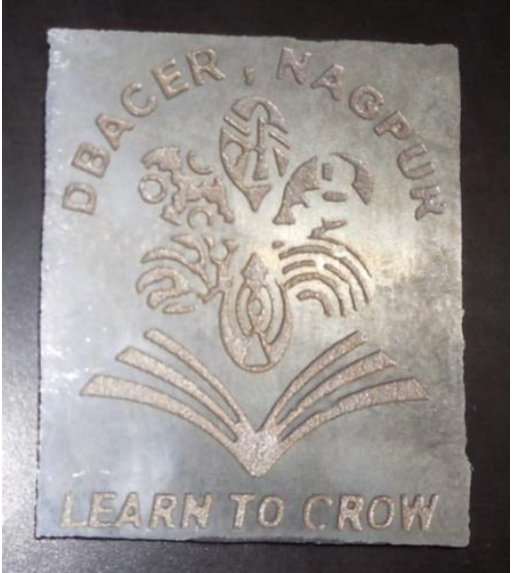

Figure 7. Tested MS Workpiece By Br Electrode

\subsection{Manufacturing Methodology No.3}

\section{(Fabrication of Aluminium Electrode by Die}

\section{Sinking EDM process)}

Due to limited time we decided to fabricate Aluminium electrode using graphite electrode created by WMC as a master tool for EDM and Aluminium as a workpiece so that we can fabricate Aluminium tool as fast as possible. The flow process diagram will give the detail of manufacturing process of EDM electrode. The first step was developing solid model of the electrode. The modeling of electrode is done using Unigraphics 9.0 version software as done in vertical milling machine Process. Next stage according to flow chart is fabrication of graphite tool, which is already completed in methodology no.1 WMC machining operation. As we already have electrode for EDM machine next stage is machining stage. In this stage machining of graphite electrode with Aluminium electrode is done at $\mathrm{I}=10 \mathrm{~A}$ for 1 hour and $15.6 \mathrm{~min}$. After machining we get finished Aluminium workpiece, which we are going to use as a electrode in this research. This Aluminium electrode is again tested on the same Die Sinking EDM using MS sheet as a workpiece at 15 A current.

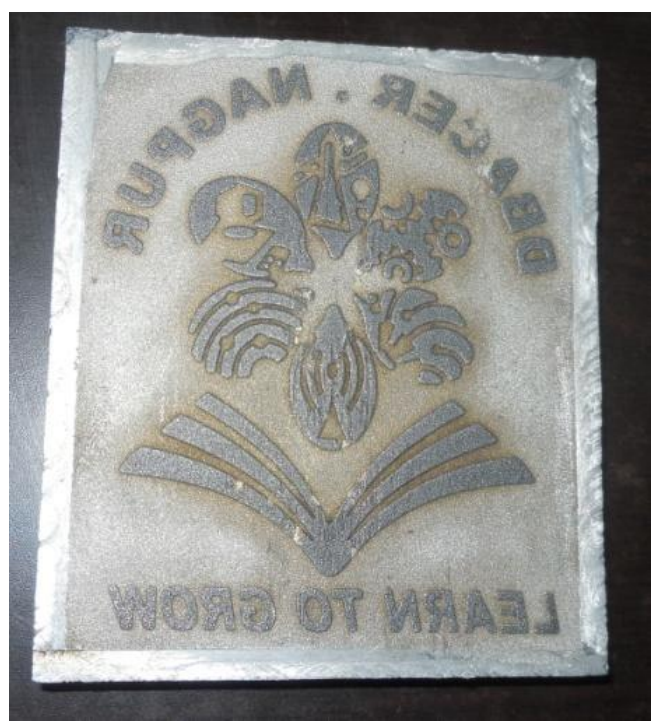

Figure 8 Finished $\mathrm{Al}$ electrode

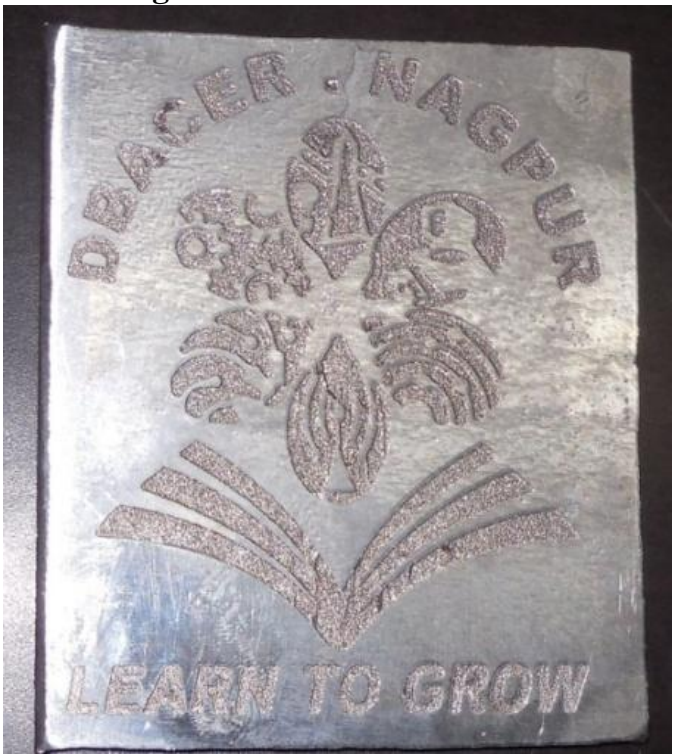

Figure 9 Tested MS Workpiece By Al Electrode

\section{CALCULATIONS AND COMPARISION OF MANUFACTURING PARAMETERS}

In this research total three experiments are carried out. from this experiment's total four electrode of four different materials are developed. To find out best optimal result we have to compare each manufacturing parameter of all four electrodes.

\subsection{Time Analysis For All Manufacturing \\ Process And Testing Of Electrodes}

Time analysis plays very important role in calculation of different parameters, thus its necessary to calculate time required for manufacturing and testing of all electrodes. Following table I show time required for manufacturing of electrodes by Vertical Milling Machining, Net Shape Casting and Die Sinking EDM Methodology. And also Shows time required for testing of each electrode at $\mathrm{I}=15 \mathrm{~A}$ on Die Sinking EDM. Following graph I shows production time testing time (on $\mathrm{X}$ - axis) plotted against various electrode (on $\mathrm{Y}$ - axis) gives detail information and idea about the time required for fabrication and testing of electrode. Aluminium Electrode Fabricated using Die Sinking EDM required highest production time compare to WMC and Net Shape Casting Method. And Copper Electrode required minimum testing time compare to other electrodes. 
Table -1 Production Time And Testing Time For All Electrodes.

\begin{tabular}{|l|l|l|l|}
\hline $\begin{array}{l}\text { Manufacturing } \\
\text { methodology }\end{array}$ & $\begin{array}{l}\text { Electrode } \\
\text { Material }\end{array}$ & $\begin{array}{l}\text { Total } \\
\text { Manufacturing } \\
\text { time } \\
\text { (Min) }\end{array}$ & $\begin{array}{l}\text { Testing } \\
\text { time for } \\
\text { Electrode }\end{array}$ \\
\hline $\begin{array}{l}\text { WMC (Vertical } \\
\text { milling machine) }\end{array}$ & Graphite & 390 & 60 \\
\hline $\begin{array}{l}\text { WMC(Vertical } \\
\text { milling machine) }\end{array}$ & Copper & 390 & 30 \\
\hline Net shape casting & Brass & 130 & 40.8 \\
\hline Die sinking EDM & Aluminium & 76 & 42 \\
\hline
\end{tabular}



Figure 10 Manufacturing Time \& Testing Time Vs. All Electrodes

\subsection{Material Removal Rate (Mrr)}

MRR is an important performance measure of EDM and many researchers research on improving mechanism of Materiel Removal in EDM. Mechanism of Material Removal means conversion of electrical energy into heat energy. It is also well known by many EDM researchers that Material Removal Mechanism is the process of transformation of material elements between tool and workpiece. There for MRR of the work piece will be measure by dividing the weight of workpiece before and after machining against the machining time that was achieved [6], [7].

The following table II contains detail information about weight of electrode, time required for testing and corresponding MRR of electrode. Graph II shows Copper having highest MRR followed by Brass, Aluminium and Graphite. MRR is plotted against all four electrodes.
Table 2. MRR of Electrodes

\begin{tabular}{|c|c|c|c|}
\hline $\begin{array}{l}\text { Electrode } \\
\text { Material }\end{array}$ & $\begin{array}{l}\text { Weight of } \\
\text { Electrode } \\
\quad(\text { gms })\end{array}$ & $\begin{array}{c}\text { Total } \\
\text { machining } \\
\text { Time } \\
\text { (min) }\end{array}$ & $\begin{array}{l}\text { MRR= } \\
\text { weight of electrode } \\
\text { total machining time } \\
\text { (gms/min) }\end{array}$ \\
\hline $\begin{array}{l}\text { Graphite } \\
\text { Copper }\end{array}$ & $\begin{array}{l}229 \\
662\end{array}$ & $\begin{array}{l}60 \\
30\end{array}$ & $\begin{array}{l}3.8167 \\
22.067\end{array}$ \\
\hline Brass & 586 & 40.8 & 14.3627 \\
\hline Aluminium & 329 & 42 & 7.833 \\
\hline
\end{tabular}



Figure 11 MRR Vs All Electrodes

\subsection{Electrode Wear Rate (Ewr)}

Proper knowledge of electrode wear is essential for determining the electrode size and number of electrodes. Electrode wear is a function of factor such as polarity, thermal conductivity, and melting point of electrode, duration and intensity of spark discharge [11]. Table III show EWR of all electrodes and Graph III shows EWR plotted against corresponding Electrodes. Copper electrode shows lowest EWR compare to other electrodes.

The EWR is measured by

$\mathrm{EWR}=\frac{\text { Weight of Electrode before machining }[\mathrm{A}](\mathrm{gms})}{\text { Weight of Electrode after machining }[\mathrm{B}](\mathrm{gms})}$ 
Table-3 Electrode Wear Rate For All EDM Electrode

\begin{tabular}{|c|c|c|c|}
\hline $\begin{array}{c}\text { Electrode } \\
\text { Material }\end{array}$ & $\begin{array}{c}\text { A } \\
\text { (gms) }\end{array}$ & $\begin{array}{c}\text { B } \\
\text { (gms) }\end{array}$ & $\begin{array}{c}\text { Electrode } \\
\text { Wear } \\
\text { Rate(EWR }\end{array}$ \\
\hline $\begin{array}{c}\text { Graphite } \\
\text { Copper }\end{array}$ & 229 & 226 & 1.01321 \\
\hline Brass & 562 & 662 & 1.0068 \\
\hline Aluminium & 329 & 328 & 1.003 \\
\hline
\end{tabular}

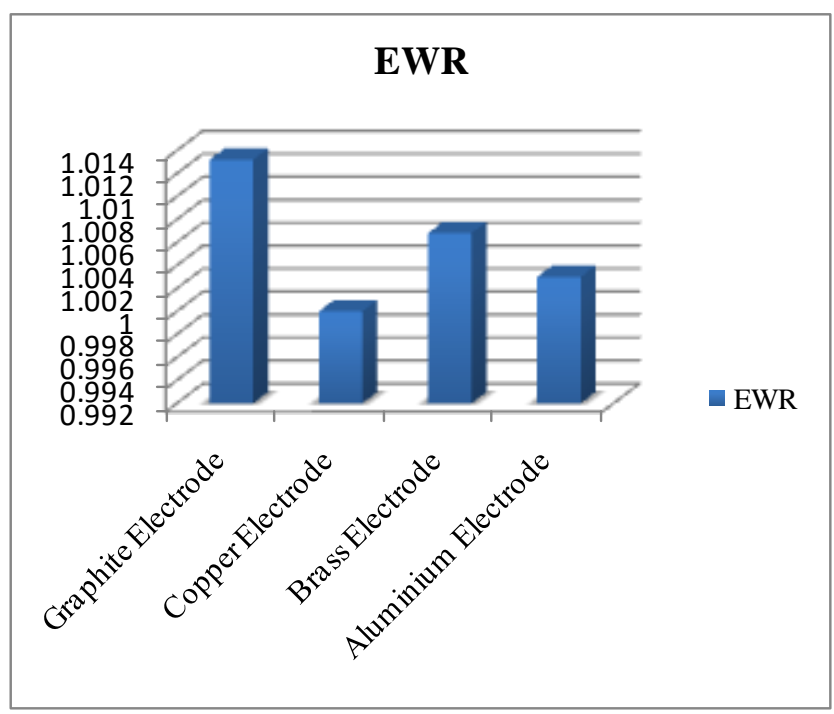

Figure 12 EWR Vs All Electrodes

\subsection{Surface Roughness (Sr)}

The Roughness Average value (Ra) is measured using a Surface roughness tester instrument. For accurate calculation of SR, reading is taken at four different points on workpiece and mean is taken to calculate SR.SR of graphite is maximum at $15 \mathrm{~A}$ current compare to other electrodes. This is explaining in below graph in figure no.

For this measurement values, I= 9Amps

DC voltage range $=45-50 \mathrm{Volt}$

Table-4 Ra values Calculated by SR Tester

\begin{tabular}{|c|c|c|}
\hline $\begin{array}{c}\text { Manufacturing } \\
\text { methodology }\end{array}$ & $\begin{array}{l}\text { Electrode } \\
\text { Material }\end{array}$ & $\begin{array}{c}\text { RaValue }(\boldsymbol{\mu m}) \\
\text { at 15 A }\end{array}$ \\
\hline $\begin{array}{c}\text { Development of } \\
\text { electrode by } \\
\text { WMC }\end{array}$ & $\begin{array}{c}\text { Graphite } \\
\text { Copper }\end{array}$ & 21.063 \\
1.2525 \\
\hline $\begin{array}{c}\text { Net shape casting } \\
\text { process }\end{array}$ & Brass & 1.2825 \\
\hline $\begin{array}{c}\text { Development of } \\
\text { electrode by die } \\
\text { sinking EDM }\end{array}$ & Aluminium & 1.2175 \\
\hline
\end{tabular}

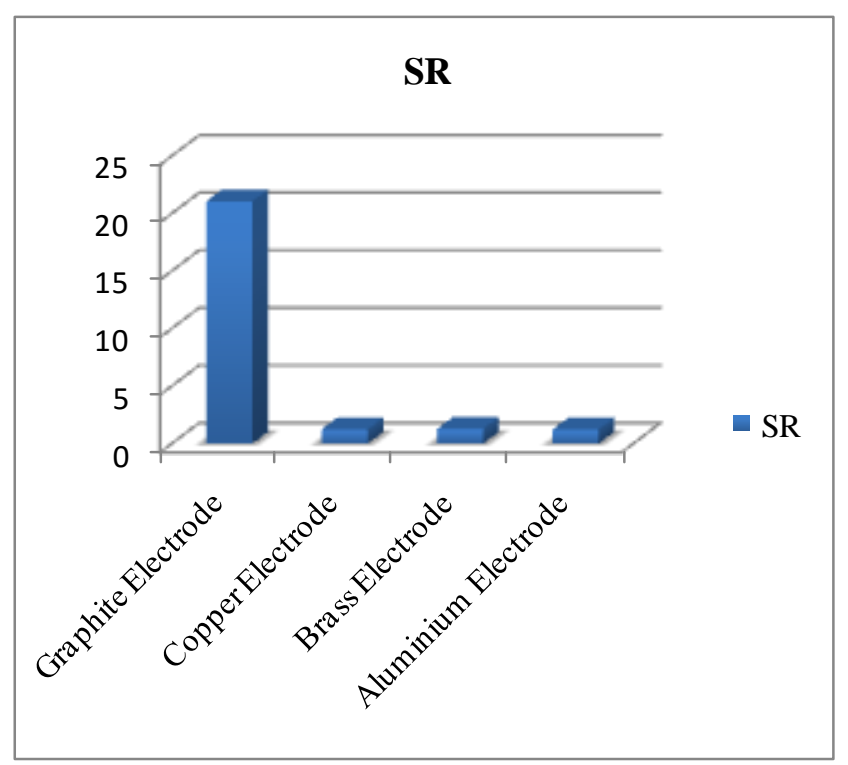

Figure 13

From all the comparisons between performance measures, time and cost Copper electrode gives moderate result compare to the Aluminium, Graphite and Brass. Second best material is Brass then Aluminium and Graphite. To validate this result optimization is done by using advanced optimization techniques SAW \& TOPSIS.

\section{OPTIMIZATION}

Selection of material for EDM electrode is one of the critical factors for decision makers in competitive environment. This research aims to find out best optimal electrode material by two optimization methods to evaluate the electrode and techniques and ranking aspect of efficacy under four criteria: MRR, EWR, SR and total Cost of electrode. The methods used for this study are "Simple Additive Weighting (SAW) and Technique for Order Preference by Similarity to an Ideal Solution (TOPSIS) [8],[9],[10]. Following table shows attributes selected for optimization.

Table 5 Performance Measures And Manufacturing Cost Of All Electrode

\begin{tabular}{|c|l|l|l|l|}
\hline Attributes & \multicolumn{1}{|c|}{ MRR } & ETW & SR & MC \\
\hline $\begin{array}{c}\text { Graphite } \\
\text { electrode }\end{array}$ & 3.8167 & 1.0132 & 21.063 & 4875 \\
\hline $\begin{array}{c}\text { Copper } \\
\text { electrode }\end{array}$ & 22.067 & 1 & 1.2525 & 4328 \\
\hline $\begin{array}{c}\text { Brass } \\
\text { electrode }\end{array}$ & 14.3627 & 1.0068 & 1.2825 & 2075 \\
\hline $\begin{array}{c}\text { Aluminium } \\
\text { electrode }\end{array}$ & 7.833 & 1.003 & 1.2175 & 2230 \\
\hline
\end{tabular}


Here, MRR- material removal rate

EWR- electrode wear rate

SR- surface roughness

MC- manufacturing cost for electrode

\subsection{Topsis Method:-}

Step 1:-Construction of normalized Matrix

This step transforms various attribute dimensions into nondimensional attributes, by using the eq. (1). To calculate the normalizing decision matrix, squaring each element of the matrix of alternatives. Then, sum the squaring elements in each column. After that, calculate the root for the sum in each column. Divide the elements in alternatives matrix of each column by the root in each column and the resulted normalized matrix stated in table7.2.

$\mathrm{rij}=\frac{x i j}{\Sigma(X i j) 2}$

let's calculate $\Sigma\left(\mathrm{X}_{\mathrm{ij}}\right)^{2}$ first for ease of calculation.

$\operatorname{MRR}=\sqrt{3.8167^{2}+22.067^{2}+14.3627^{2}+7.833^{L}}$

$=27.7337$

$\mathrm{EWR}=\sqrt{1.0132^{2}+1^{L}+1.0068^{2}+1.2825^{L}+1.2175^{L}}$ $=2.0115$

$\mathrm{SR}=\sqrt{21.063^{2}+1.2525^{2}+1.2825^{2}+1.2175^{2}}$ $=21.1741$

$\mathrm{MC}=\sqrt{4875^{2}+4328^{2}+2075^{2}+2230^{2}}$

$=7195.5356$

Now, normalized matrix can be calculated as,

$\mathrm{rij}=\frac{x i j}{\Sigma(x i j) 2}$

Table 6 Normalized Matrix

\begin{tabular}{|c|l|l|l|l|}
\hline Attributes & MRR & EWR & SR & MC \\
\hline $\begin{array}{c}\text { Graphite } \\
\text { electrode }\end{array}$ & 0.1376 & 0.5037 & 0.9947 & 0.6775 \\
\hline $\begin{array}{c}\text { Copper } \\
\text { electrode }\end{array}$ & 0.7956 & 0.4971 & 0.0591 & 0.6014 \\
\hline $\begin{array}{c}\text { Brass } \\
\text { electrode }\end{array}$ & 0.5178 & 0.5005 & 0.0605 & 0.2883 \\
\hline $\begin{array}{c}\text { Aluminium } \\
\text { electrode }\end{array}$ & 0.2824 & 0.4986 & 0.0574 & 0.3099 \\
\hline
\end{tabular}

Step 2:- calculation of weight Relative importance matrix



$\mathrm{MRR}+\mathrm{EWR}+\mathrm{SR}+\mathrm{MC}=1.5650+1.3195+0.5285+1$

$=4.413$

Weight( $\mathrm{Wj})$ : -

$\operatorname{MRR}=\frac{1.5650}{4.413}=0.3546$

$\mathrm{SR}=\frac{1.3195}{4 / 413}=0.2990$

$\mathrm{EWR}=\frac{0.5285}{4 / 413}=0.1197$

$\mathrm{MC}=\frac{1}{4,413}=0.2266$

$\Sigma \mathrm{MRR}+\mathrm{EWR}+\mathrm{SR}+\mathrm{MC}=0.9999$

$\approx 1$

Now, we have to check consistency of weights

[A1] = Relative importance matrix

$\mathrm{Wj}=$ 
$[A 3]=[A 1][A 2]$

$=\left[\begin{array}{cccc}1 & 2 & 3 & 1 \\ 0.5 & 1 & 4 & 2 \\ 0.33 & 0.25 & 1 & 0.5 \\ 1 & 0.5 & 2 & 1\end{array}\right]\left[\begin{array}{l}0.3546 \\ 0.2990 \\ 0.1197 \\ 0.2266\end{array}\right]$

$\mathrm{A} 4]=\frac{[\mathrm{A} 3]}{[\mathrm{A} 2]}$
Step 3:-Construct the weighted normalized decision matrix by using below eq. In this step Multiply each column of the normalized decision matrix by its associated weight.

$\mathrm{Vij}=\mathrm{Wj} \mathrm{x}$ Tij

MRR EWR SR MC

$\begin{array}{lllll}\text { MRR } & 0.0487 & 0.1506 & 0.119 & 0.1531\end{array}$

$\begin{array}{lllll}\text { EWR } & 0.2821 & 0.1138 & 0.007 & 0.1359\end{array}$

$\begin{array}{lllll}\text { SR } & 0.1836 & 0.1496 & 0.0072 & 0.0651\end{array}$

$\begin{array}{lllll}\text { MC } & 0.1001 & 0.149 & 0.0068 & 0.0700\end{array}$

Step 4:-Determine the ideal and negative ideal solutions. Ideal solution is calculated by using the eq. (3). It is the maximum of performance and safety and minimum in cost. Negative ideal solution is calculated by using the eq. (4) and it is reverse to the Ideal solution. The ideal and negative ideal solution are presented in table no. 7 .

$\mathrm{A}^{*}=\left\{\mathrm{Vj}^{*},{ }_{--\ldots}, \mathrm{Vn}^{*}\right\}$

Where,

$V j=\{\max (V i j)$ if $j \in j ; \min i(V i j)$ if $j \in j\}$

$\mathrm{A}^{\prime}=\left\{\mathrm{Vj}^{*}\right.$, $, \mathrm{Vn} *\}$

Where,

$V j=\{\min (V i j)$ if $j \in j ; \max (V i j)$ if $j \in j\}$

From above equations, calculated positive and negative ideal solution are given in following table 7

Table 7 Calculated Positive And Negative Ideal Solutions

\begin{tabular}{|l|l|l|}
\hline & Positive ideal solution & Negative ideal solution \\
\hline MRR & 0.282 & 0.0487 \\
\hline EWR & 0.1138 & 0.1506 \\
\hline SR & 0.119 & 0.0068 \\
\hline MC & 0.0651 & 0.1531 \\
\hline
\end{tabular}

Calculations of separation measures using Euclidian formula

$\mathrm{Si}^{+}=\sqrt{\sum_{j}\left(V i j-V j^{*}\right)^{2}}$ 
$\mathrm{Si}^{-}=\sqrt{\sum_{j}(V i j-V j)^{2}}$

From above equations, calculated positive and negative separation measures are given in following table no. 8

Table 8 Calculated Separations Measures

\begin{tabular}{|l|l|l|}
\hline & $\mathrm{S}^{+}$ & $\mathrm{S}^{-}$ \\
\hline S1 (MRR) & 0.2520 & 0.1122 \\
\hline S2 (EWR) & 0.1325 & 0.2369 \\
\hline S3 (SR) & 0.1531 & 0.1610 \\
\hline S4 (MC) & 0.2166 & 0.09772 \\
\hline
\end{tabular}

Step 5 :- Calculate similarities to positive ideal solutions, from equation no.(7)

$\mathrm{Ci}=\frac{s_{i}}{s_{i}{ }^{+}+s_{i}}$

$$
\begin{aligned}
\text { Graphite } & =\frac{s_{1}}{s_{1}{ }^{+}+s_{1}} \\
& =\frac{0.2520}{0.1122+0.2520}
\end{aligned}
$$$$
=0.3080
$$

$$
\begin{aligned}
\text { Copper } & =\frac{s_{2}}{s_{2}{ }^{+}+s_{2}} \\
& =\frac{0.2369}{0.2369+0.1325} \\
& =0.6431
\end{aligned}
$$

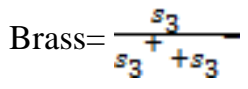

$$
=\frac{0.1610}{0.1610+0.1531}
$$$$
=0.5125
$$

Aluminium $=\frac{s_{4}}{s_{4}{ }^{+}+s_{4}}$

$$
\begin{aligned}
& =\frac{0.09772}{0.09772+0.2166} \\
& =0.3108
\end{aligned}
$$

Step 6 :- Rank Preference Order

In this step Alternatives are Ranked according to similarities in descending order. This is shown in following table no. 9

Table 9 Calculated similarities to Positive Ideal Solutions

\begin{tabular}{|l|l|}
\hline Alternatives & $\mathrm{Ci}^{*}$ \\
\hline Graphite & 0.03080 \\
\hline Copper & 0.6413 \\
\hline Brass & 0.5125 \\
\hline Aluminium & 0.3108 \\
\hline
\end{tabular}

Table 9 Calculated similarities to Positive Ideal Solutions From above table no. 7.5 Rank preference order will be, Copper electrode<smiles>C1CCCC1</smiles>

Brass electrode<smiles>C1CC2CCC1C2</smiles>

Aluminium electrode<smiles>C1CCCC1</smiles>

Graphite electrode

\subsection{Saw Method}

Step 1- Obtain the normalized decision matrix from the decision matrix using the Following equation,

$r i j=x i j / x j *$ (7) if the jth criterion is a benefit criterion,

$r i j=x j-\mid x i j$ (8) if the jth criterion is a cost criterion

$\begin{array}{llccc} & \text { MRR } & \text { EWR } & \text { SR } & \text { MC } \\ \text { MRR } & 0.1729 & 0.9869 & 1 & 0.4264 \\ & & & & \\ \text { EWR } & 1 & 1 & 0.0594 & 0.4794 \\ & & & & \\ \text { SR } & 0.6508 & 0.9932 & 0.0608 & 1 \\ & & & & \\ & & & & \\ \text { MC } & 0.3549 & 0.9970 & 0.0578 & 0.9304\end{array}$


Step 2:- Calculation of weight

Calculations of weights are same as in TOPSIS method

$\mathrm{Wj}=\left[\begin{array}{c}0.3546 \\ 0.2990 \\ 0.1197 \\ 0.2266\end{array}\right]$

Step 3 :- Calculation of weighted normalize matrix

Obtain the weighted decision matrix by multiplying each column normalized decision

matrix by the corresponding weight

$\mathrm{Vi}=\sum_{j=1}^{m} W j V j$

Graphite $=0.1729 \times 0.3546+0.09869 \times 0.299+0.1197+0.4264 \times 0.2266$

$$
=0.5727
$$

Copper $=0.3546+0.299+0.0594 \times 0.1197+0.4798 \times 0.2266$

$$
=0.7694
$$

Brass $=0.3546 \times 0.6508+0.299 \times 0.9932+0.1197 \times 0.0608+0.2266$

$$
=0.0 .7616
$$

Aluminium $=0.3546 \times 0.354+0.299 \times 0.9970+0.1197 \times 0.0578+0.2266 \times 0.9304$

$$
=0.6416
$$

Step 4:- Rank Preference Order

In this step Alternatives are ranked according to similarities in descend order.

Copper electrode<smiles>C1CCCC1</smiles>

Brass electrode<smiles>C1CCCCC1</smiles>

Aluminium electrode<smiles>C1CCCCC1</smiles>

Graphite electrode

In this topic optimization of process parameters is done to find out optimal combination of electrode and workpiece. This optimization is done using TOPSIS \& SAW methods.
From both the methods its clear that Copper is best EDM Electrode among $\mathrm{Br}, \mathrm{Gr} \& \mathrm{Al}$. both the methods gives same rank order preference, which shows that preference given to selection of material for EDM tool are exact and calculations done in both the methods are accurate. From both methods its clearly shown that Copper is best material for EDM electrode then $\mathrm{Br}, \mathrm{Al} \& \mathrm{Gr}$ respectively. From this optimization results from comparisons between Performances measures (MRR, EWR, SR), Cost and Time analysis is also validated.

\section{CONCLUSION}

1. The MRR increases with changes in material of the different manufacturing methods. In the present work the highest material removal rate (22.067) was obtained in Copper Electrode by WMC Process. Material removal rate of Brass $=14.3627$, Aluminium $=7.833$ and Graphite $=3.8167$

2. Optimized Electrode wear rate was observed maximum in Copper Electrode $=1$. Machining time for the copper electrode was $30 \mathrm{~min}$. Electrode wear rate of Brass $=1.0068$, Aluminium $=1.003$ and Graphite $=1.0132$

3. The optimized surface roughness value in all manufacturing process was observed in Graphite electrode of the WMC process. Other electrode having very low surface roughness compare to other electrode surface roughness of Graphite $=21.063 \mu \mathrm{m}$, Copper $=1.2525 \mu \mathrm{m}$, Brass $=1.2825 \mu \mathrm{m}$ Aluminium $=1.2175 \mu \mathrm{m}$

4. While manufacturing the EDM Electrode through different manufacturing methods, the electrode manufacture by Die sinking EDM \& Net shape casting requires less time for production but the manufacturing parameters were greatly affected.

5. Optimization is done using two advanced methods of optimization based on multiple criteria decision ngking (MADM) problem. Optimization is done base on the multiple criteria including MRR, EWR, SR and MC (manufacturing cost). From SAW \& TOPSIS methods of optimization optimal rank of electrode is find out. Both methods give the same rank. These methods suggests Copper is best EDM electrode followed by Brass, Aluminium and Graphite.

\section{REFERENCES}

[1] Kumar Sandeep , Status of recent developments and research issues of electrical discharge machining, International Journal of Latest Trends in Engineering and Technology (IJLTET)

[2] Anand Pandey and Shankar Singh, Current research trends in variants of Electrical Discharge Machining: A review, International Journal of Engineering Science and Technology Vol. 2(6), 2010, 2172-2191

[3] D.M. Guo*, M. Zhang, Z.J. Jin and B.X. Zuo, Particle strengthening of the surface of copper electrode for electrical discharge machining, Int. J. Materials and Product Technology, Vol. 31, No. 1, 2008 
[4] K.S.BankeR, A.D. Oza and R.B. Dave, Performance Capabilities of EDM machining using Aluminum, Brass and Copper for AISI 304L Material, International Journal of Application or Innovation in Engineering \& Management (IJAIEM), Volume 2, Issue 8, August 2013

[5] Roger Kern, Sinker electrode material selection, EDM Today, July/ August 2008 issue

[6] Kumar Sandeep , Review Paper Current Research Trends in Electrical Discharge Machining: A Review , Research Journal of Engineering Sciences , 2278 9472 Vol. 2(2), 56-60, February (2013)

[7] Kuldeep Ojha, R. K. Garg, K. K. Sing, MRR Improvement in Sinking Electrical Discharge Machining: A Review, Journal of Minerals \& Materials Characterization \& Engineering, Vol. 9, No.8, pp.709-739, 2010

[8] Ruta simanaviciene and LionasUstinovichius, Sensitivity Analysis for Quantitnive Dicisio Making Methods : SAW \& TOPSIS

[9] Seyed Mohammad HosseinHojjati and AlirezaAnvary, An Integrated SAW, TOPSIS Method for Ranking the Major Lean Practices Based on Four Attributes, World Applied Sciences Journal 28 (11): 1862-1871, 2013 ISSN 1818-4952

[10] Mohammed F. Aly, Hazem A. Attia and Ayman M. Mohammed, Integrated Fuzzy (GMM) -TOPSIS Model for Best Design Concept and Material Selection Process, International Journal of Innovative Research in Science, Engineering and Technology, Vol. 2, Issue 11, November 2013 